\title{
APAKAH TOTAL QUALITY MANAGEMENT MENINGKATKAN MUTU SEKOLAH MENENGAH ATAS DI KOTA CIREBON?
}

\author{
Asep Kurniawan \\ Program Studi Manajemen Pendidikan Islam, IAIN Syekh Nurjati, Cirebon, \\ Jawa Barat, Indonesia \\ Email: asepkurniawan@syekhnurjati.ac.id
}

DOI: http://doi.org/10.33650/al-tanzim.v4i2. 1234

\begin{tabular}{l|l|l} 
Received: June 2020 & Accepted: August 2020 & Published: September 2020
\end{tabular}

\begin{abstract}
:
This paper aims to determine the implementation of total quality management in state and private senior high schools in Cirebon City and to compare the level of their implementation. This research is a descriptive exploratory study. The instrumens of collecticting data are questionnaires, observation and interviews. Data are analyzed using descriptive and statistical t-test. The analysis finds that total quality is implemented by state and private high schools. However, the level of application is significantly different ( $\mathrm{t}$-value $=9,208, \mathrm{p}$-value $=<0,0001$ ). State senior high schools applys it very well, and private schools applys it well. The Differences of total quality management are in all measured aspects. The observation shows that the state senior high schools implemented maximum total quality management, while the private senior high schools implement it not optimally, due to limited resources. The implication is the higher organization's resources, the more optimal implementation of total quality management.
\end{abstract}

Keywords: total quality management, public senior high school, private senior high school

Abstrak:

Penelitian ini bertujuan untuk mengetahui implementasi total quality management di Sekolah Menengah Atas (SMA) negeri dan swasta di kota Cirebon, serta untuk membandingkan tingkat implementasinya. Penelitian ini adalah penelitian eksplorasi deskriptif. Instrumen pengumpulan data meliputi kuesioner, observasi dan wawancara. Data dianalisis dengan menggunakan uji-t deskriptif dan statistik. Analisis menemukan bahwa TQM telah dilaksanakan oleh SMA negeri dan swasta. Akan tetapi tingkat penerapannya berbeda-beda secara signifikan (nilai- $t=9,208$, nilai-p $=<0,0001)$, di mana SMA negeri mampu menerapkan pada tingkat yang sangat baik, sementara sekolah swasta berada pada tingkat yang baik. Perbedaan dalam penerapan total quality management terjadi di semua aspek yang terukur. Hasil pengamatan menunjukkan bahwa SMA negeri sudah menerapkan total quality management secara maksimal, sedangkan di SMA swasta lebih rendah karena keterbatasan sumber daya. Implikasinya bahwa semakin tinggi sumber daya organisasi maka semakin optimal dalam menerapkan total quality management.

Kata Kunci: total quality management, sekolah menengah atas negeri, sekolah menengah atas swasta 


\section{PENDAHULUAN}

Pendidikan yang bermutu menjadi harapan setiap masyarakat, bangsa, dan negara. Menurut Koslowski (2006), di era persaingan yang ketat ini, pendidikan berkualitas adalah perhatian utama. Akan tetapi, dewasa ini dunia pendidikan di Tanah Air belum seutuhnya bisa merespon harapan masyarakat. Kondisi ini ditandai dengan rendahnya kualitas lulusan, penyelesaian persoalan pendidikan yang tidak sampai selesai. Akibatnya, acapkali hasil pendidikan tidak sejalan dengan harapan masyarakat. Mutu lulusan pendidikan kurang menjawab kebutuhan pembangunan dan pasar tenaga kerja yang cenderung menggugat keberadaan sekolah. Bahkan, Sumber Daya Manusia yang dihasilkan melalui pendidikan sebagai generasi penerus belum secara optimal memuaskan jika ditinjau dari segi moral, akhlak, dan jati diri bangsa dalam pluralitas budaya bangsa.

Fenomena ini mengakibatkan banyak masyarakat cenderung pesimis terhadap sekolah. Sekolah kurang menjanjikan masa depan siswa yang lebih baik. Perubahan paradigma baru pendidikan kepada kualitas adalah diantara strategi guna mencapai pembinaan keunggulan pribadi peserta didik. Dalam konteks pembangunan bangsa, peningkatan kualitas pendidikan, terutama pendidikan menengah, adalah target pembangunan di bidang pendidikan nasional (Fadhli, 2017).

Dengan demikian, sistem pendidikan yang berkualitas perlu ditanamkan kepada generasi baru yaitu peserta didik di Sekolah Menengah Atas (SMA). Hanya saja, lembaga pendidikan saat ini masih dihadapkan pada kurangnya penggunaan kualitas manajemen dan menghasilkan sistem pendidikan yang rendah. Untuk mempercepat ide itu, ada satu filosofi manajemen yang muncul, yaitu total quality management. Total quality management ini telah menerima pengakuan luas sebagai pendekatan yang efektif untuk mencapai peningkatan kualitas pendidikan (Terzic, 2017).

Penelitian ini merupakan upaya teoritis yang merujuk kepada teori Sallis (1993), Wani \& Mehraj (2014), Todorut (2013) untuk menganalisis penerapan total quality management di SMA. Hal ini berkaitan dengan masalah-masalah dalam hal kualitas di SMA dan bergerak untuk mengidentifikasi variabel yang mempengaruhi kualitas SMA. Penelitian ini juga membuat konsep model untuk penerapan total quality management di SMA.

Teori-teori baru di bidang ekonomi menekankan peran Sumber Daya Manusia sebagai kunci pertumbuhan dan pembangunan ekonomi. Studi terbaru Bank Dunia terhadap 190 negara mengungkapkan bahwa SMA membantu dalam memperkaya kualitas tenaga kerja. Berbagai ukuran mutu output sektor pendidikan jelas menunjukkan bahwa para siswa di Indonesia masih tertinggal cukup jauh di belakang. Indonesia terus menduduki peringkat rendah dalam tes standar internasional untuk kinerja siswa, bahkan setelah memperhitungkan kondisi sosial ekonomi.

Hasil dari Trend in International Mathematics dan Science Study (TIMMS) pada tahun 2011 memperlihatkan bahwa kecakapan lebih dari setengah siswa seluruh Indonesia dalam mata pelajaran ilmu pengetahuan alam dan matematika berada di bawah tingkat kemahiran dasar, Indonesia berada di 
peringkat 52 dari 56 negara (Suryadarma \& Sumarto, 2011). Dalam Program untuk Penilaian Siswa Internasional (PISA) 2006, yang melihat seberapa baik siswa berusia 15 tahun dipersiapkan untuk hidup mandiri, Indonesia peringkat sekitar 50 dari 57 negara dalam sains, membaca dan matematika. Para siswa tidak siap untuk memenuhi tuntutan masyarakat ketika mereka lulus dari SMA dan perguruan tinggi. Para siswa tersebut adalah produk dari sistem pendidikan yang tidak fokus pada kualitas yang dikembangkan oleh guru yang berkualitas.

Guru yang berkualitas identik dengan guru yang bersertifikasi. Pada tahun 2007, Departemen Pendidikan Nasional Indonesia memprakarsai Program Sertifikasi Guru, yang dirancang untuk menstandarisasi dan meningkatkan kualitas guru di Indonesia. Program ini didirikan untuk menanggapi fakta bahwa kualitas guru jauh di bawah standar. Pemerintah Indonesia memilih pendidikan sebagai salah satu prioritas tertinggi dalam strategi pembangunannya. Dengan memiliki kualitas pendidikan yang baik, diharapkan generasi penerus bangsa Indonesia akan mampu mengatasi tantangan pembangunan untuk memastikan kesejahteraan (Kardiyem, 2013), kemajuan dan kemakmuran Bangsa (Kartowagiran, 2011). Program peningkatan kualitas guru merupakan strategi penting untuk meningkatkan kualitas pendidikan (Nye et al., 2004), dan darinya mutu pengajaran dibangun sebagai penerapan Total Quality Management (Barber et al., 2007). Meskipun pada faktanya sertifikasi guru juga tidak serta merta mendongkrat kompetensi guru dalam mengajar.

Kualitas guru berperan penting dalam menentukan daya saing suatu bangsa, lebih-lebih di era globalisasi (Sujianto, 2013). Indonesia telah mengakui pentingnya meningkatkan kualitas pendidikan, khususnya kualitas guru, untuk memasok negara dengan sumber daya manusia yang berdaya saing tinggi. 65\% dari total 2,7 juta guru di Indonesia belum memenuhi persyaratan sebagai guru profesional, sehingga diperlukan strategi jenius untuk menghasilkan guru profesional untuk mengisi guru lokal dan nasional atau bahkan internasional. Hal itu dapat dilakukan jika masyarakat dan pemerintah bekerja sama untuk mencapai peningkatan kualitas guru. Jika seseorang menerima premis bahwa kualitas guru menghasilkan kualitas siswa, maka prestasi siswa yang buruk dapat dikaitkan dengan buruknya kualitas guru di Indonesia (Jalal et al., 2009).

Salah satu masalah yang dihadapi oleh Bangsa Indonesia adalah rendahnya kualitas pendidikan di setiap tingkatan, termasuk kualitas masalah Sumber Daya Manusia (HRI). Laporan Organisasi Pendidikan, Ilmu Pengetahuan, dan Budaya Perserikatan Bangsa-Bangsa (UNESCO), yang dirilis pada hari Kamis, 29 November 2007, menunjukkan peringkat Indonesia dalam hal pendidikan turun dari 62 di antara 130 negara di dunia. Jelas, Indeks Pembangunan Pendidikan (EDI) Indonesia adalah 0,935, yang berada di bawah Malaysia (0,945) dan Brunei Darussalam (0,965) (Rachman, 2011).

Masalah yang mungkin dihadapi oleh SMA dalam penerapan Total Quality Management adalah mutu dan relevansi pendidikan, yakni masih rendahnya persentase lulusan SMA yang dapat memenuhi persyaratan untuk 
meneruskan ke strata perguruan tinggi. Padahal tujuan pelaksanaan pendidikan SMA ialah untuk menyiapkan siswa mengikuti pendidikan tinggi. Oleh sebab itu fungsinya lebih kepada menyiapkan siswa dalam kerangka akademik serta dasar-dasar pengetahuan sebagai acuan yang kuat bagi tumbuh kembang sikap dan moral sebagai ilmuwan. Salah satu penyebab yang membawa masalah ini ke permukaan adalah kurangnya sarana prasarana pendidikan yang berkualitas.

Terlebih lagi, kekurangan kapasitas pembangunan dan motivasi siswa untuk belajar lebih giat. Ini berarti bahwa peningkatan manajemen mutu di SMA sangat bermanfaat untuk mencapai potensi pendidikan berkualitas tinggi yang memenuhi standar semua latar belakang sekolah nasional. Sebagian besar ditemukan bahwa sesuatu yang masih tersisa untuk memperlambat kualitas pendidikan adalah kurangnya kinerja guru yang baik dalam menyampaikan materi secara metodologis dan pedagogis kepada siswa. Kurangnya evaluasi teoritis dan praktis dari sistem ujian di sekolah-sekolah juga termasuk dalam kekurangan kualitas pendidikan. Selain itu, adanya tingkat lulusan yang berbeda dari SMA negeri dan swasta menghasilkan ketimpangan kemampuan di dunia kerja yang memudarkan latar belakang mereka di masyarakat.

Menurut penelitian Zaman \& Anjalin (2016), proses menuju kualitas total dalam pendidikan adalah proses yang lambat dan mantap; butuh waktu, perubahan ini bisa dicapai dengan kesabaran, kerja sama, dan bantuan. Selanjutnya, setiap institusi harus menjadi organisasi pembelajaran yang berfokus pada pengembangan individu, serta pemberdayaan semua staf.

Sementara itu, penelitian Hasan et al. (2018) menunjukkan bahwa sistem pendidikan dasar saat ini tidak berkembang pesat dengan globalisasi yang dinamis. Itulah sebabnya manajemen kualitas total dapat mengatasi masalah saat ini terkait dengan sistem pendidikan dasar Bangladesh. Beberapa rekomendasi diberikan dalam penelitian ini untuk meningkatkan kualitas pendidikan tingkat dasar di sekolah-sekolah Bangladesh. Peran para guru sangat dihargai. Tanggung jawab guru untuk menetapkan sumber daya untuk manajemen kualitas total yang dialokasikan waktu untuk berbagai program pelatihan, menghargai siswa yang datang dengan berbagai ide peningkatan, dan mendorong mereka.

Berpijak penelitian pendahuluan tanggal 3-6 Januari 2019 ditemukan data awal bahwa SMA Negeri dan swasta yang ada di Cirebon sudah berupaya menerapkan TQM hal ini terlihat diantaranya dari upaya memberikan pelayanan akademik terhadap konsumen pendidikan atau siswa dengan sebaik apa bisa mereka lakukan, seperti dengan membuka kotak keluhan, saran atau masukan terhadap layanan tersebut untuk dijadikan sebagai bahan pengembangan lebih lanjut. Namun dengan status yang berbeda antara negeri dan swasta nampaknya memiliki kecenderungan penerapan yang berbedabeda secara umum yang berdampak pada mutu kedua status lembaga tersebut. Hal ini sepertinya dari faktor pendanaan yang lebih cenderung kuat di sekolah negeri. 
Untuk mengatasi kesenjangan penelitian sebelumnya, penelitian memfokuskan pada kajian perbadingan penerapan TQM di sekolah negeri dan swasta yang berbasis di perkotaan belum nampak ke permukaan khasanah riset manajemen pendidikan terlebih menyangkut aspek mutu SDM, sarana prasarana, evaluasi, dan pengembangan yang dikaji secara bersama. Oleh sebab itu, peneliti tertarik untuk mengungkap sejauhmana TQM diterapkan di SMA di Kota Cirebon.

\section{METODE PENELITIAN}

Penelitian ini adalah penelitian kuantitatif dengan metode statistik untuk menggambarkan dengan baik penerapan dan analisis total quality management di Sekolah Menengah Atas. Penelitian ini menggunakan desain deskriptif survei dengan penyelidikan fakta dari berbagai jenis. Dalam ilmu sosial dan penelitian ekonomi, istilah 'penelitian deskriptif' cukup sering digunakan. Karakteristik utama dari metode ini adalah bahwa peneliti tidak memiliki kendali atas variabel; dia hanya dapat melaporkan apa yang telah terjadi atau apa yang terjadi. Penelitian ini menggunakan studi deskriptif di mana para peneliti berusaha untuk mengukur beberapa item, misalnya, Mean, SD, preferensi orang, atau data serupa. Penelitian ini dikategorikan sebagai penelitian deskriptif yang menggambarkan untuk mengeksplorasi semua faktor tentang total quality management di Sekolah Menengah Atas, untuk mencari ada atau tidaknya peran antara variabel yang diteliti di mana dalam hal ini adalah peran informasi antara variabel siswa dan guru. Penelitian ini dilakukan di lima sekolah menengah negeri dan lima Sekolah Menengah Atas swasta di Kota Cirebon yang mengambil jurusan ilmu sosial dengan membandingkannya dalam pelaksanaan total quality management.

Pengambilan sampel kelompok melibatkan pemilihan kelompok secara random, bukan individu. Subjek kemudian dipilih secara acak, untuk menjaga peluang yang sama agar secara keseluruhan, karena pemilihan siswa dan guru menggunakan teknik proportional cluster random sampling (Isaac dan Michael, 1995). Penelitian ini dilakukan pada akhir Januari sampai awal September 2019.

Populasi penelitian adalah semua guru dan siswa yang ada di lima sekolah menengah negeri dan swasta di Kota Cirebon yang telah menerapkan total quality management sebagaimana dapat dilihat pada table berikut:

Tabel 1 : Sekolah Menengah Atas Negeri dan Swasta di Kota Cirebon
\begin{tabular}{lll} 
No & \multicolumn{1}{c}{ Negeri } & \multicolumn{1}{c}{ SMA } \\
\hline 1 & SMAN 3 & SMA Islam Al-Azhar \\
\hline 2 & SMAN 4 & SMA Widya Utama \\
\hline 3 & SMAN 5 & SMA Sekar Kemuning \\
\hline 4 & SMAN 6 & SMA Taman Siswa \\
\hline 5 & SMAN 7 & SMA Windu Wacana \\
\hline
\end{tabular}


Dalam proses analisis data, peneliti menggunakan statistik uji-t. Sebelum tes dilakukan, peneliti memberikan beberapa tes untuk menentukan penggunaan statistik distribusi data parametrik t-test. Selanjutnya hasil tes tersebut dianalisis untuk memastikan homogenitas varians dengan dua sekolah yang mempunyai varian yang setara untuk perbandingan.

\section{HASIL DAN PEMBAHASAN}

Hasil penelitian memperlihatkan adanya perbedaan dalam pelaksanaan total quality management di Sekolah Menengah Atas negeri dan swasta. Pengukuran total quality management di Sekolah Menengah Atas meliputi lima aspek, yaitu; 1) akses sarana prasarana; 2) kualitas pengembangan; 3) kualitas guru; 4) kualitas sistem evaluasi; dan 5) latar belakang akademik para guru. Kelima aspek penerapan TQM tersebut jelas membutuhkan sumber daya yang tidak kecil, dan membutuhkan pula dukungan yang berkesinambungan untuk penerapan total quality management, namun hal tersebut bukanlah sesuatu yang sifatnya kaku, sebab mekanisme manajemen senantiasa tidak dapat dipisahkan dari proses pendidikan.

Dalam pendidikan menengah, banyak masalah kualitas yang mengelilinginya, seperti rendahnya kualitas sistem manajemen, kurangnya kualitas sarana prasarana dan akses fasilitas, kualitas pembelajaran, kualitas dan kinerja profesional guru, kualitas yang terkait dengan kepemimpinan pendidikan dan dukungan manajerial pihak yang terkait dengan pendidikan. Memang, rendahnya kualitas lulusan berasal dari kelemahan komponen kualitas pendidikan ini, termasuk dalam aspek manajemen, khususnya ditekankan pada total quality management.

Total quality management adalah upaya yang sistematis dalam mengontrol kualitas siswa secara eksplisit dalam suatu institusi (organisasi). Total quality management mungkin cocok untuk fungsi belajar-mengajar, yang merupakan inti dari pendidikan di sekolah. Total quality management menawarkan solusi bagi lembaga pendidikan untuk mengelola diri mereka sendiri secara efektif dalam masa perubahan yang cepat dan mempertahankan fokus yang jelas pada tujuan pendidikan yang esensial dan dominan (Sallis, 1993).

Sebagai solusi untuk memilih pengembangan, beberapa manfaat dan kelebihan yang ditawarkan oleh Sekolah Menengah Atas sebagai modal utama bagi orang untuk memilih pendidikan menengah ialah meningkatkan akhlak mulia, kepribadian, pengetahuan, kecerdasan, dan keterampilan untuk hidup mandiri dan meneruskan pendidikan lebih lanjut pada jenjang yang lebih tinggi serta untuk mengembangkan diri sesuai dengan perkembangan ilmu dan teknologi.

Kualitas di Sekolah Menengah Atas meliputi semua fungsi dan kegiatan terkait dari bagian masyarakat dan kehidupan akademik di sebuah institusi. Untuk itu, setiap kerangka kerja untuk penilaian kualitas harus diperhitungkan dari kemanfaatannya bagi individu, masyarakat, bangsa dan negara. Kualitas tersebut, yaitu kualitas guru, kualitas administrasi dan layanan sekolah, sarana dan prasarana yang diberikan kepada siswa, serta sumber daya manusia. 
Suatu institusi pendidikan bisa berkembang menjadi sekolah efektif apabila dikelola dengan manajemen yang efektif pula. Manajemen dalam lembaga pendidikan merupakan penerapan konsep, teori, dan prinsip manajemen dalam kegiatan pendidikan untuk mencapai tujuan pendidikan secara efektif dan efisien (Ibrahim \& Abdalla, 2017). Diantara upaya dalam memperbaiki manajemen lembaga pendidikan ialah dengan menerapkan total quality management, yaitu ilmu manajemen yang mengarahkan pimpinan organisasi dan para personilnya untuk memperbaiki kualitas secara terus menerus dan fokus pada pemenuhan kepuasan pelanggan (Gasperszt, 2005).

Secara umum, SMA swasta di Kota Cirebon ini telah banyak mengalami perkembangan kemajuan. Beberapa diantaranya menghantarkan kepada labelitas sekolah favorit yang banyak diminati masyarakat, seperti SMA Islam al Azhar dan SMA Sekar Kemuning. Labelitas ini mencerminkan kemampuan manajemen sekolah tersebut untuk dapat mengatasi masalah pendanaan. Fakta ini juga memperlihatkan bahwa tidak ada kemampuan penjelas tunggal penerapan total quality management terhadap perbedaan antara Sekolah Menengah Atas negeri dan swasta.

Manajemen inovasi seperti yang dipraktikkan di SMA swasta favorit dapat diterapkan saat kebijakan pemerintah mendukungnya. Status guru Sekolah Menengah Atas negeri adalah pegawai negeri sipil yang mendapatkan gaji dan pensiun, di sisi lain, Sekolah Menengah Atas swasta dengan guru yang tidak menerima gaji dan pensiun yang layak adalah masalah yang memerlukan penyelesaian dari kebijakan pemerintah. Hal-hal ini menunjukkan bahwa perbedaan dalam tingkat penerapan total quality management di SMA negeri dan swasta terkait erat dengan kebijakan pemerintah.

Perbedaan penerapan total quality management pada aspek peningkatan kualitas baik kualitas pengembangan, kualitas guru, kualitas sistem evaluasi, dan latar belakang akademik guru di Sekolah Menengah Atas sangat sulit dikelola ketika Sekolah Menengah Atas swasta tidak mendapatkan bantuan yang cukup dari pemangku kebijakan, dalam hal ini adalah pemerintah. Aspekaspek ini terikat oleh hukum dan peraturan dalam pelaksanaannya. Bantuan secara berkesinambungan mungkin dibutuhkan bagi sekolah untuk meningkatkan penerapan total quality management. Penerapan TQM dapat dilihat sebagai berikut:

Tabel 2 : Penerapan Total Quality Management di Sekolah Menengah Atas Kota Cirebon

\begin{tabular}{llrrr}
\hline \multirow{2}{*}{ No } & \multicolumn{2}{c}{ Indikator } & \multicolumn{2}{c}{ SMA } \\
& \multicolumn{1}{c}{ Negeri } & Swasta \\
\hline 1 & Sarana prasarana dan akses total quality & 3.180 & 2.999 \\
& management di Sekolah Menengah Atas negeri & & \\
\hline 2 & Kualitas pengembangan & 3.350 & 3.128 \\
\hline 3 & Kualitas guru & 3.393 & 3.069 \\
\hline 4 & Kualitas sistem evaluasi & 3.511 & 3.198 \\
\hline 5 & Latar belakang akademik guru & 3.359 & 3.153 \\
\hline
\end{tabular}

Sumber: Diolah Peneliti tahun 2019 
Dari analisa data yang berhasil peneliti lakukan, didapatkan temuan penelitian, yaitu penerapan total quality management telah terlaksana dengan baik. Temuan ini dapat diindikasikan dari (1) sarana prasarana dan akses total quality management di SMA negeri $(x=3.180)$ dan swasta $(x=2.999)$ yang dinilai sama-sama baik. Hal tersebut disebabkan guru dan siswa 'tidak merasakan' akses sarana dan prasarana di sekolah yang lain, dan itu mungkin akan berubah setelah membandingkan penilaian. (2) Kualitas pengembangan di SMA negeri $(x=3.350)$ lebih baik daripada di sektor swasta $(x=3.128)$. (3) Kualitas guru di SMA negeri (x 3.393) lebih baik daripada di sektor swasta ( $\mathrm{x}=$ 3.069). (4) Kualitas sistem evaluasi SMA negeri $(x=3.511)$ lebih baik daripada di SMA swasta $(x=3.198)$. (5) Latar belakang akademik guru di SMA negeri ( $x$ $=3.359)$ lebih baik daripada di SMA swasta $(x=3.153)$. Hasil studi ini bertentangan dengan hasil penelitian di sekolah-sekolah Punjab Pakistan oleh Muhammad Tahir Farooqi, et al (2015:91-105) yang mengatakan bahwa penerapan TQM di sekolah-sekolah swasta yang lebih baik jika dibandingkan dengan penerapan TQM di sekolah-sekolah negeri. Hal ini berakibat pada lulusannya yang lebih berkualitas.

Temuan tersebut sangat penting untuk dicatat bagi Sekolah Menengah Atas, pemangku kepentingan, dan terutama instansi yang terkait, yaitu Kementerian Pendidikan dan Kebudayaan. Hasil analisis penerapan manajemen mutu di SMA negeri lebih tinggi dari pada SMA swasta. Perbedaannya terlihat dari hasil uji statistik dan analisis data dari keseluruhan total quality management. Membandingkan skor total manajemen mutu di SMA negeri dan swasta terlihat dari kualitas sarana prasarana yang ada. SMA swasta yang memiliki skor rata-rata terendah pada sarana prasarana pendidikan sebagai bagian dari penerapan total quality management. Jika peneliti juga membandingkan seluruh sarana akses sarana prasarana, kualitas pengembangan, kualitas guru, kualitas sistem evaluasi, latar belakang akademik guru di SMA negeri dan SMA swasta, peneliti menemukan bahwa SMA negeri memiliki rerata kualitas tertinggi jika dibandingan dengan SMA swasta. Ini berarti bahwa SMA negeri memiliki potensi lebih besar dan mereka lebih maju dalam menerapkan TQM daripada SMA swasta.

Analisis ini mengungkapkan bahwa sistem manajemen baru pendidikan di SMA negeri dan swasta sedang meningkat dan berkembang, tetapi SMA swasta masih di bawah tingkat kualitas SMA negeri. Juga ditunjukkan bahwa penilaian kinerja guru dan keterampilan siswa lebih tinggi daripada di SMA swasta. Hal ini menunjukkan bahwa sistem evaluasi semisal ujian di SMA negeri lebih tertata dengan baik daripada di SMA swasta. Dengan demikian, ada keseimbangan antara SMA yang harus tunduk bahkan diatur secara rinci dengan kebebasan SMA untuk merumuskan dan mencapai target organisasi. Untuk meningkatkan sistem manajemen pembelajaran yang baik, dibutuhkan dukungan dari semua pihak yang terkait, seperti dari guru-guru dan dari kepala sekolah yang akan melakukan sistem strategi implementasi yang terdiri dari dari: pemberdayaan guru profesional untuk menciptakan suasana pembelajaran yang kondusif dan memotivasi guru untuk mengembangkan kompetensi akademik. Sebagaimana premis bahwa mutu guru menghasilkan 
mutu siswa, dalam arti prestasi siswa dapat dikaitkan dengan mutu guru (Jalal, et al., 2009).

Pengembangan penerapan total quality management di SMA negeri sudah maju dan lebih signifikan untuk meningkatkan kinerja siswa daripada di SMA swasta. Hal ini terlihat salah satunya dari latar belakang akademik guru. Di lembaga pendidikan negeri ini, para guru dikatagorikan cukup berkualitas dan dapat dengan mudah menyesuaikan dengan perangkat teknologi pembelajaran.

Ini menunjukkan bahwa ada hubungan yang kuat antara kompetensi guru dan kinerja siswa. Apa yang telah diajarkan dan diterapkan guru di kelas berdampak pada hasil siswa. Meskipun kesadaran akan pentingnya kualitas pendidikan, terutama guru, telah dilakukan untuk meningkatkannya, pemerintah Indonesia harus memperhatikan standar prestasi siswa. Buruknya prestasi siswa mungkin mencerminkan rendahnya kualitas guru di Indonesia.

Seperti yang diungkapkan dalam penelitian Kurniawan (2016) bahwa masalah makro, yakni masalah yang ada dalam pendidikan itu sebagai suatu sistem dengan berbagai sistem lainnya yang lebih luas di dalam semua kehidupan manusia, diantaranya yaitu masalah kurang meratanya pendidikan, rendahnya kualitas pendidikan, masalah relevansi, efisiensi, dan lain-lain. Berkaitan dengan permasalahan yang acapkali terjadi di Indonesia, guru dinilai sebagai sumber dari persoalan tersebut, sehingga melalui pengidentifikasian permasalahan pendidikan kita dapat menemukan mengetahui duduk permasalahan yang sebenarnya dan berupaya untuk memecahkan permasalahan tersebut.

Statistik dari Kementerian Pendidikan Nasional (2008) menunjukkan bahwa guru di Indonesia memiliki tingkat kualifikasi akademik yang relatif lebih rendah daripada guru-guru di negara tetangga. Lebih dari 60 persen dari total 2,78 juta guru belum mencapai tingkat kualifikasi akademik gelar sarjana empat tahun (D4 / S1). Kualifikasi akademik berkaitan erat dengan kualitas guru sebagaimana yang diangkat dalam penelitian ini sebagai salah satu factor pembangun total quality management.

Tingkat penerapan total quality management antara SMA negeri dan swasta berbeda secara signifikan (nilai-t $=9,208$, nilai-p $=<0,0001$ ), dimana SMA negeri dapat menerapkannya pada tingkat yang sangat baik, sedangkan SMA swasta dapat menerapkannya pada tingkat yang baik. Perbedaan ini terjadi dalam seluruh aspek yang terukur, yaitu akses sarana prasarana, kualitas pengembangan, kualitas guru, kualitas sistem evaluasi, dan latar belakang akademik guru.

Berpijak pada temuan tersebut di atas, SMA dalam menciptakan prestasi belajar siswa dapat diatur. Terkait erat dengan pentingnya TQM termasuk akses sarana prasarana pendidikan, kualitas pengembangan, kualitas guru, kualitas sistem evaluasi dan latar belakang akademik guru di SMA. Hal tersebut didukung oleh Sallis (1993), Wani \& Mehra (2014), dan Todorut (2013) bahwa TQM harus didukung oleh pemberdayaan guru, mutu pengembangan, kualitas evaluasi, dan fasilitas pendidikan. 
SMA memiliki manajemen yang baik dan iklim sekolah yang baik akan lebih cenderung memiliki siswa yang berkualitas baik (Ghias \& Ahmed, 2012; Lezotte, 2010; Syahril, 2018). Sebaliknya, sekolah yang memiliki manajemen yang tidak memadai juga akan berdampak pada kekurangan kualitas siswa (Niculescu \& Frant,, 2016). Tujuan dari manajemen mutu adalah untuk mengembangkan budaya komitmen total terhadap proses pendidikan yang kualitas di SMA untuk mencegah pemborosan.

Kolaborasi sekolah diperlukan untuk mewujudkan tujuan TQM. Kolaborasi didefinisikan sebagai wujud kerjasama berbagai pihak untuk menciptakan lembaga formal dengan validitas dan akuntabilitas dalam memaksimalkan pemberdayaan sumber daya yang ada. Kolaborasi terwujud jika masing-masing pihak memiliki tujuan dan motivasi yang sama. Sekolah yang melakukan kolaborasi yang baik, cenderung memiliki kualitas siswa yang lebih baik.

Sekolah Menengah Atas sebagai institusi pendidikan diatur oleh beberapa batasan seperti batasan peraturan dan Undang-Undang yang berlaku. Oleh sebab itu, untuk meningkatkan penerapan total quality management, peran pemerintah bersifat proaktif, baik melalui regulasi maupun undang-undang.

\section{KESIMPULAN}

Total quality management telah dilaksanakan oleh Sekolah Menengah Atas negeri dan swasta, di kota Cirebon. Akan tetapi tingkat penerapannya berbedabeda secara signifikan (nilai-t $=9,208$, nilai-p $=<0,0001$ ), di mana Sekolah Menengah Atas negeri mampu menerapkan pada tingkat yang sangat baik, sementara sekolah swasta berada pada tingkat yang baik. Perbedaan dalam penerapan total quality management terjadi di semua aspek yang terukur, yaitu akses sarana prasarana pendidikan, kualitas pengembangan, kualitas guru, kualitas sistem evaluasi dan latar belakang akademik guru yang lulus dari Sekolah Menengah Atas. Khususnya, pada aspek akses sarana dan prasarana pendidikan, meskipun secara rata-rata mereka berbeda secara signifikan, kategorinya berada di level yang sama. Perbedaannya tidak terlalu besar. Hasil pengamatan di lapangan selama penelitian menunjukkan bahwa SMA sudah menerapkan total quality management secara maksimal, sedangkan di SMA swasta lebih rendah karena keterbatasan sumber daya yang ada. Implikasinya bahwa semakin tinggi sumber daya organisasi yang dimiliki oleh SMA, maka semakin optimal dalam menerapkan total quality management.

\section{DAFTAR PUSTAKA}

Barber, M., Mourshed, M., \& Company, M. and. (2007). How The World's BestPerforming Schools Systems Come Out on Top. New York: McKinsey \& Company.

Fadhli, Muhammad. (2017). Manajemen Peningkatan Mutu Pendidikan. TADBIR : Jurnal Studi Manajemen Pendidikan, 1(2), 215-240. 
Farooqi, M.T.K., F. Arshad, G. Qadir. (2015). Comparative Study of TQM Principles Applied at Public and Private Secondary School in Punjab, Pakistan. Journal of Quality and Technology Management, 11(2): 91-105.

Gasperszt, V. (2005). Total Quality Management. Jakarta: Gramedia Pustaka Utama.

Ghias, F., \& Ahmed, A. (2012). A Study of the Effect of Management Styles on Performance of Students at Secondary Level in Sargodha. Procedia-Social and Behavioral Sciences, 46, 2523-2527.

Hasan, K.M., Islam, M.N., Shams, A., \& Gupta, H. (2018). Total Quality Management (TQM): Implementation in Primary Education System of Bangladesh. International Journal of Research, 7(3), 370-380.

Ibrahim, A. A., \& Abdalla, M. S. (2017). Educational Management, Educational Administration and Educational Leadership: Definitions and General concepts SAS Journal of Medicine ( SASJM ) Educational Management, Educational Administration Leadership: Definitions and General concepts and. SAS Journal of Medicine (SASJM), 3(6), 2454-5112. https:// doi.org/10.21276/sasjm.2017.3.12.2

Jalal, F., Samani, M., Chang, M. C., Stevenson, R., Ragatz, A. B., \& Negara, S. D. (2009). Teacher Certification in Indonesia: A Strategy for Teacher Quality Improvement. Jakarta: The Ministry of National Education and the World Bank.

Kardiyem. (2013). Analisis Kinerja Guru Pasca Sertifikasi: Studi Empiris pada Guru Akuntansi SMK Se-Kabupaten Grobogan. JEE: Journal of Economic Education, 2(1), 18-23.

Kartowagiran, Badrun. (2011). Kinerja Guru Profesional (Guru Pasca Sertifikasi). Jurnal Cakrawala Pendidikan, 30(3), 463-473.

Khoirunnisa. (2012). Profil Kompetensi Guru Pendidikan Agama Islam SMPN di Kota Bekasi. Jurnal Tarbawi, 1(3), 205-219.

Koslowski, A. F. (2006). Quality and Assessment in Context: A Brief Review. Quality Assurance in Education, 14, 277-288.

Kurniawan, \& Yonisa, R. (2016). Identifikasi Permasalahan Pendidikan di Indonesia untuk Meningkatkan Mutu dan Profesionalisme Guru. Konvensi Nasional Pendidikan Indonesia (KONASPI) VIII Di Universitas Negeri Jakarta, 1415-1420.

Lezotte, L. W. (2010). What Effective Schools Do: Re-Envisioning the Correlates. Indianapolis. IN: Solution Tree.

Mukhadis, S. A., \& Isnandar. (2013). Pengembangan Profesionalitas Berkelanjutan Guru Bersertifikat Pendidik di SMK Rumpun Teknologi se-Malang Raya. Jurnal Pendidikan Sains, 1(2), 1-16.

Niculescu, M., \& Franț, A. I. (2016). The Influence of Classroom Management Quality on the Students' Behaviour. Romanian Journal of English Studies, 13(1), 154-157.

Nye, B., Konstantopoulos, S., \& Hedges, L. V. (2004). How Large are Teacher Effects?. Educational Evaluation and Policy Analysis, 26, 237-257. Educational Evaluation and Policy Analysis, 26(3), 237-257. 
Rachman, Taufik. 2011. Kualitas Pendidikan Turun Gara-gara Otonomi Daerah? https://www.republika.co.id/berita/nasional/umum/11/11/30/lvheiq -kualitas-pendidikan-turun-garagara-otonomi-daerah diakses tanggal 30 November 2019

Sallis, Edward. (1993). Total Management in Education. London: Kogan Page.

Suryadarma, D., \& Sumarto, S. (2011). Survey of Recent Developments. Bulletin of Indonesian Economic Studies, 47(2), 155-181.

Syahril, Hadiyanto. (2018). Improving School Climate for Better Quality Educational Management. Journal of Educational and Learning Studies, 1(1), 16-22.

Terzic, Emina, (2017). The Implementation of Total Quality Management (TQM) as a Function of Improving Education. Fascicle of Management and Technological Engineering, 3, 11-15.

Wani, I. A., \& Mehraj., H. K. (2014). Total Quality Management in Education: An Analysis. International Journal of Humanities and Social Science Invention, 3(6), 71-78.

Zaman, A. S. M., Sohel-Uz-, \& Anjalin, U. (2016). Implementing Total Quality Management in Education: Compatibility and Challenges. Open Journal of Social Sciences, 4(11), 207-217. 